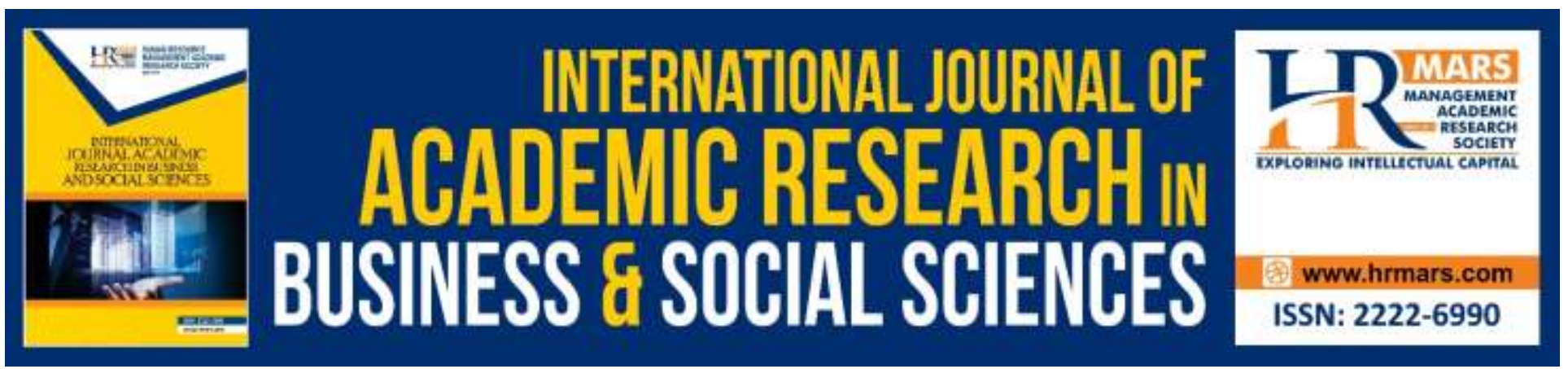

\title{
Drama Activities as Tool for Socialization of Learners with Autism
}

\section{Shirley N. Cerbo, Norfishah Mat Rabi}

To Link this Article: http://dx.doi.org/10.6007/IJARBSS/v9-i6/6102

DOI: $10.6007 /$ IJARBSS/v9-i6/6102

Received: 12 April 2019, Revised: 20 May 2019, Accepted: 02 June 2019

Published Online: 29 June 2019

In-Text Citation: (Cerbo \& Rabi, 2019)

To Cite this Article: Cerbo, S. N., \& Rabi, N. M. (2019). Drama Activities as Tool for Socialization of Learners with Autism. International Journal of Academic Research in Business and Social Sciences, 9(6), 1250-1261.

\section{Copyright: (C) 2019 The Author(s)}

Published by Human Resource Management Academic Research Society (www.hrmars.com)

This article is published under the Creative Commons Attribution (CC BY 4.0) license. Anyone may reproduce, distribute, translate and create derivative works of this article (for both commercial and non-commercial purposes), subject to full attribution to the original publication and authors. The full terms of this license may be seen

at: http://creativecommons.org/licences/by/4.0/legalcode

$$
\text { Vol. 9, No. 6, 2019, Pg. } 1250-1261
$$

Full Terms \& Conditions of access and use can be found at http://hrmars.com/index.php/pages/detail/publication-ethics 


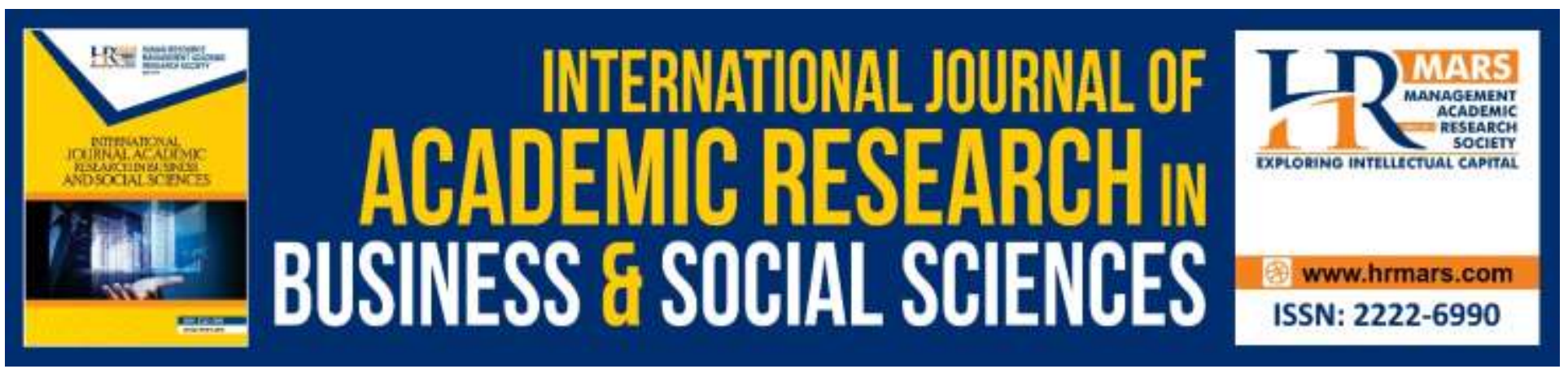

\title{
Drama Activities as Tool for Socialization of Learners with Autism
}

\author{
Shirley N. Cerbo ${ }^{1}$, Norfishah Mat Rabi² \\ Faculty of Education Sciences, Philippine Normal University, Manila, Philippines ${ }^{1}$ \\ Faculty of Human Development, Universiti Pendidikan Sultan Idris, Perak, Malaysia²
}

\begin{abstract}
This study aims to describe the process of the development of a creative drama module that could be used as tool for the socialization of learners with autism. Objectives of the study are to identify common socialization deficits of learners with ASD and to develop a module using drama activities. This descriptive study is conducted to investigate how drama activities could be used as tool to help learners with autism engage in social interaction. Data were collected through interviews, observations, and checklist analysis. Semi-structured questions were used in the interviews. Instruments used were interview questions, observation field notes and evaluation checklist. Descriptive analysis was used to examine the collected data. Findings of the study show that learners with ASD share common deficits in socialization; drama activities are helpful in encouraging social interaction among learners with ASD and the module in creative drama could be used as a tool for the socialization. Implication of the study is to provide information to school and center administrators, regular and classroom teachers, and parents of learners with autism on the use of the drama module as a tool for enhancing socialization of learners with autism. Conclusion is that learners with ASD could be helped to improve socialization with others through the use of drama activities.
\end{abstract}

Keywords: Autism Spectrum Disorder, Socialization, Creative Drama, Module

\section{Introduction}

Creative drama is the use of creative and expressive process of art to enhance physical,-mental, emotional, and social well-being of individuals through art, music, dance movement and drama (Orkibi, 2014). Through the process of creation, imagination, playfulness, movement and dramatic structure, verbal barriers are connected. Drama, particularly, makes use of movements, of using the voice and the body to create and to express. Drama for children generally uses Creative Dramatics where improvisational activities and theater games enable the learners to express themselves and to socialize. It encourages interaction and collaboration which are essential in the development of social 
skills. It is the purpose of this study to use of drama as a tool in the enhancement of socialization among children with Autism Spectrum Disorder (ASD).

According to the United Nations, $1 \%$ of the global population is on autism spectrum (Autism Society of the Philippines, 2012). In the Philippines, close to a million of the approximately 102 plus million population deal with autism spectrum Disorder (Autism Society of the Philippines 2016). Persons with ASD are lacking in social competence and have deficiencies in social interaction. Their lack of social skills has made students with ASD the object of teasing, victimization, and bullying by their peers, especially in high school where social differences become more evident and important within peer groups. As the learners reach adolescence, their social impairments become more noticeable when demands for social interaction surpass social skills. Many times, learners with autism suffer in silence. Not knowing how to socialize and interact with others, they continue to exist in isolation. Deficits in socialization negatively affect the learners' emotion.

\section{Literature Review}

Social skills deficits can affect learners with autism's interactions with family, peers, and other adults. Limited social abilities can affect their ability to attain normal developmental milestones and to form satisfying peer and familial relationships (Gates, Kang, \& Lerner, 2017). These deficits adversely affect the quality of their lives and their independence. There are occasions where the lack of social skills of these learners become a deterrent for their inclusion in inclusive education classrooms (Karal \& Wolfe, 2018). Furthermore, the success of these learners in school is severely limited by their lack of social skills (Gustavsen, 2017).

Social interaction is important for a child to be accepted. According to Caplan et al. (2016), social skills teaching for learners with ASD is imperative to lessen the impact of its deficits in their lives and to help them cope with their environment. It is of utmost importance that this group of learners be taught social skills to help them develop successful social friendships (Agran, et al., 2016).

The American Association of Theatre for Youth defined Creative Dramatics or Creative Drama as "an improvisational, non-exhibitional, process-centered form of drama in which participants are guided by a leader to imagine, enact and reflect upon human experience". McCaslin (2006) in her book noted that activities used in Creative Drama always involve improvisation, where the participants create the dialogue which what is not intended for an audience. A skilled leader, not a theater director, possibly the classroom teacher, guides the participants in the dramatic activities. The leader acts as facilitator of the creative processes where each of the participants are led to create, take on characters, and explore voice and movement from different situations. The facilitator must be encouraging but not pushy, giving instruction that is clear, well organized, and very thoughtful. This gives the participants freedom to express themselves creatively in a non-threatening environment. It is important for teachers to think of activities that will help develop social relationships among learners with special needs. Enabling the forming of friendships among learners 
whether in school or outside the school is beneficial to all the learners and to the staff (Macnamara, 2015).

Creative Dramatics as a tool in enhancing socialization provides experiences that are interesting and meaningful. Through these experiences, children develop skills in shared attention, social reciprocity, social involvement, and emotional engagement (Conn, 2013). As a learner becomes engaged in active role taking situations, the learner starts to develop a concept of his own role. This in turn will help him achieve a better understanding of himself and a better sensitivity and interactions towards others. All these are done within the context of an environment that is free and is accepting of differences. Wheater (2013), in her study advanced the use of theatre stressing that it could have a great impact in the social and emotional development of learners with autism. Theatre intervention is a highly beneficial approach for children with autism because it aids in the development of social and emotional skills. Drama is a learning medium is relatively under-used in specialist settings. There is a need for teachers to have trainings on it so as to develop skills on its use. Likewise, it is essential for more research on this field so as to maximize its potential (Kempe \& Tissot, 2012). There is also a need for the development of instructional materials on the use of drama as tool for socialization enhancement.

Learning could be individualized through the use of modular instruction (Torrefranca, 2017). Padmapriya (2015) defines a module as a small unit of instruction which deals with a single conceptual unit of subject matter". It is independent and self-contained and has as its main concern the attainment of a few well defined objectives. A module is an instructional material that could be helpful in guiding the teacher in formulating aims of teaching a subject. It provides instructors the procedures to follow in the preparation of materials that will support the realization of the goals of designed course (Nardo, 2017). Modules are helpful in guiding teachers present a particular course with ease and with guided directions. A module provides complete information on how to facilitate activities that would lead to the attainment of the goals set.

According to Donnelly and Fitzmaurice (2005), the process of making a module, involves forging educationally sound and logical links between the needs of the learners, the aims, the learning outcomes, needed resources, the learning and teaching strategies, the assessment criteria and the evaluation. Likewise, it is important that a module must hinge on theories that underpin learning, because this will have a bearing on the strategies that will be employed. Every module must have three important elements. First, the learning outcomes are clearly defined; next, the use of drama as teaching and learning approach that would lead to the attainment of the outcomes are identified; and finally, the evaluation checklist of the students' learning outcomes is provided (Biggs, 1999).

The module also has the following parts as proposed by Donnelly et al. (2005). These are the module overview, the aims and the learning outcomes, the module content, the learning strategies and appropriate learner support, the assessment, and the module evaluation strategy. The overview of the module involves its goal of providing an instructional material that could be used by teachers, parents or care givers. The learning outcomes refer to what the learners were expected to do during 
and at the end of the learning period (Moon, 2002). Assessment can be formative, to find out how the students are progressing. Assessment is also summative, where the children's' over-all performance is evaluated at the end of the activities. This research study was guided by relevant theories and models. The theories and the models help in clarifying the concepts related to the study and in the preparation of activities pertinent to topic of the research. A model is a presentation of a detailed statement to explain an occurrence or a phenomenon. A theory is a set of declarations that is established through a process of continued thoughts. Both provide framework for observation and understanding.

The theories of Bandura (1976) and Vygotsky (1978) both view learning as a social thing. The students learn through interaction with people within the context where they presently are. Social interaction enhances the learning process. This study has underpinnings in the social learning theory of Bandura (1976) and the sociocultural theory of Vygotsky (1978).

The Building Blocks Model, a creative dramatics model by Volkenburg (2015) is used in this study. The model uses the techniques in creative drama by Way (1967). As quoted by Carkin (2007), Brian Way was a pioneer creative dramatist who created drama techniques based on developmental learning to nurture the whole child. He was one of the pioneers of the drama-in-education movement and advocated that drama should be included in the mainstream curriculum. Van Volkenburg (2015) adopted his techniques and developed the model which involves concentration, pantomime, movement to sound, moods and emotions (role playing), voice and diction, storytelling, and playmaking/improvisation. The techniques were presented in a hierarchical process. Each part of the block creates a foundational skill essential in building the succeeding skills. The Building Block Model provides an organized way of using the creative drama approach in teaching. Activities were arranged in a hierarchy which develop from simple to complex.

\section{Methodology}

This qualitative study describes the process of the development of a creative drama module. Purposive sampling is used in this study. The sample of six learners with ASD is used in the study. Data were collected through interviews, observations and document analysis. Individual interview sessions were conducted to get qualitative data from the respondents who are the teachers and the parents of the learners with ASD. Instruments used in collecting data are interview questions, checklist and field notes. The checklist used in the collection of data was developed by the researcher and was subjected to validation by five experts in the field of study. The case study was analyzed and reported descriptively and supported by reference statistics. Result of the case study was used in the development of a creative drama module. The module was subjected to validation by five experts in Special Education and creative drama.

\section{Results}

The findings refer to the identified socialization deficits of learners with ASD; the important elements of the creative drama module and the explanations why the activities in the module are useful as a tool for the socialization of the learners with ASD. 
INTERNATIONAL JOURNAL OF ACADEMIC RESEARCH IN BUSINESS AND SOCIAL SCIENCES

Vol. 9, No. 6, June, 2019, E-ISSN: 2222-6990 (C) 2019 HRMARS

1) Socialization deficits of learners with ASD

Table 1

Common socialization deficits of learners with ASD

\begin{tabular}{|c|c|c|c|c|c|}
\hline \multirow[t]{2}{*}{ Behavior Deficit } & \multicolumn{3}{|c|}{$\begin{array}{l}\text { Number of times behavior is } \\
\text { Mentioned or demonstrated }\end{array}$} & \multirow[t]{2}{*}{ Total } & \multirow[t]{2}{*}{ Frequency } \\
\hline & Interview & Observation & Checklist & & \\
\hline $\begin{array}{l}\text { Lacks interest in being } \\
\text { with others }\end{array}$ & 23 & 12 & 9 & 44 & $44.4 \%$ \\
\hline $\begin{array}{l}\text { Lacks initiative in joining } \\
\text { group activities }\end{array}$ & 21 & 1 & 4 & 26 & $26.3 \%$ \\
\hline $\begin{array}{l}\text { Does not readily } \\
\text { exchange social smiles }\end{array}$ & 5 & 1 & 1 & 7 & $7.1 \%$ \\
\hline $\begin{array}{l}\text { Does not initiate to relate } \\
\text { with others }\end{array}$ & 5 & 2 & 5 & 12 & $12.1 \%$ \\
\hline Prefers solitary activities & 3 & 3 & 4 & 10 & $10.1 \%$ \\
\hline
\end{tabular}

Table 1 shows that based on the multiple sources of data, the behavior deficit mostly manifested by the learners is that of lacking interest in being with others. It has a frequency of $44.4 \%$. The learners' lack of initiative in joining group activities got a frequency of $26.3 \%$. the behavior deficit of not initiating to relate with others got a frequency of $12.1 \%$ and the learners' preference for solitary activities got a frequency of $10.1 \%$.

2) The important elements of the creative drama module

With the common behavior deficits identified, a module was developed with the aim of being used as a tool for the socialization of learners with ASD. As a tool, the module provides activities with teacher prompted directions to guide the learners, in order for them to manifest and acquire the skills as specified by the set goals. 
Table 2

Summary of expert assessors' validation

\begin{tabular}{|c|c|c|c|c|c|c|c|}
\hline \multirow[t]{3}{*}{ Criteria } & \multirow[t]{3}{*}{ Indicators } & \multicolumn{5}{|c|}{ Expert Assessors } & \multirow{3}{*}{$\begin{array}{l}\text { Average } \\
\text { Rating }\end{array}$} \\
\hline & & & & & & & \\
\hline & & YSQ & AMN & RM & MCC & NCP & \\
\hline \multirow[t]{4}{*}{ Language } & $\begin{array}{l}\text { The statements are direct and } \\
\text { specific. }\end{array}$ & 3 & 4 & 4 & 3 & 3 & 3.4 \\
\hline & $\begin{array}{l}\text { The directions are easy to } \\
\text { understand. }\end{array}$ & 3 & 4 & 4 & 3 & 3 & 3.4 \\
\hline & Sentences are concise. & 3 & 4 & 4 & 3 & 3 & 3.4 \\
\hline & $\begin{array}{l}\text { Directions are easy to follow. } \\
\text { The format of the module is }\end{array}$ & 3 & 4 & 4 & 3 & 3 & 3.4 \\
\hline \multirow[t]{3}{*}{ Format } & $\begin{array}{l}\text { acceptable. } \\
\text { There are no mechanical errors }\end{array}$ & 3 & 4 & 4 & 4 & 3 & 3.6 \\
\hline & $\begin{array}{l}\text { (ex: alignment, spacing, spelling, } \\
\text { etc.). }\end{array}$ & 3 & 3 & 4 & 4 & 3 & 3.4 \\
\hline & $\begin{array}{l}\text { The font type, size, and spacing } \\
\text { used are reader-friendly }\end{array}$ & 3 & 4 & 4 & 4 & 3 & 3.6 \\
\hline \multirow[t]{3}{*}{ Activities } & $\begin{array}{l}\text { The activities are appropriate for } \\
\text { target participants. }\end{array}$ & 4 & 4 & 4 & 3 & 4 & 38 \\
\hline & $\begin{array}{l}\text { The activities do not pose } \\
\text { danger to the safety of the } \\
\text { participants. }\end{array}$ & 4 & 4 & 4 & 3 & 4 & 3.8 \\
\hline & $\begin{array}{l}\text { The activities are useful in } \\
\text { developing the focus skills } \\
\text { The module contents are }\end{array}$ & 4 & 4 & 4 & 3 & 4 & 3.8 \\
\hline \multirow[t]{3}{*}{$\begin{array}{l}\text { Relationship } \\
\text { to Problem }\end{array}$} & $\begin{array}{l}\text { sufficient to answer the research } \\
\text { questions. }\end{array}$ & 4 & 4 & 4 & 3 & 3 & 3.6 \\
\hline & $\begin{array}{l}\text { The module contents are } \\
\text { sufficient to obtain the purpose } \\
\text { of the study. }\end{array}$ & 4 & 4 & 4 & 3 & 3 & 3.6 \\
\hline & & & & & & & 3.55 \\
\hline
\end{tabular}

\section{Score}

1= Not Acceptable (major modifications needed)

2= Below Expectations (some modifications needed)

$3=$ Meets Expectations (no modifications needed but could be improved with minor changes)

4= Exceeds Expectations (no modifications needed) 
The module is designed to use creative drama activities that will help address the socialization deficits of children with ASD. Each activity in the module targets the acquisition of the skills. The flow of the module activities follows the Building Blocks Model in Creative Drama by Van Volkenburg (2015). The module has been validated by five experts in the field of Special Education and in Creative Drama. Table 2 illustrates the summary of evaluation of the creative drama module by the five experts. Generally, the expert assessors evaluated the module by giving it an average rating of 3.55. This shows that the creative drama module meets all the expectations of the experts with no modifications needed but could be improved with minor changes. The highest ratings given by the expert is 3.8 in the area of the module activities. They generally found the activities to be appropriate for target participants; do not pose danger to the safety of the participants and are useful in developing the focus skills. The experts found the module contents are sufficient to answer the research questions and are sufficient to obtain the purpose of the study. This got an average rating of 3.6. The format of the module got an average of 3.5, showing that the format of the module is acceptable; there are no mechanical errors in alignment, spacing and spelling and the font type, size, and spacing used are reader-friendly. Finally, the use of language in the module got an average rating of 3.4. This indicates that generally, the statements are direct and specific.; the directions are easy to understand; the sentences are concise and the directions are easy to follow.

The important elements are the parts of the module activities. These are the following:

Session Title which gives an introduction on what the session focus will be. The first session focuses on preliminaries. The following sessions comprise the whole seven building blocks of creative drama. The last three sessions focus on the preparations and the closing activities.

Activity gives the title of the particular activity for the day. The title of each session is created using a catchy phrase that tells an idea of what the session is about.

Time Allotted is the part which tells how long a session will run. Typically, each session runs for 30 minutes but there are sessions that are longer that require 60 minutes or two meetings.

Teaching Aids are the instructional materials that are needed to be used in each session. These include visuals, manipulatives, chart, real objects.

Directions are the numbered steps or procedure that tells the facilitator on what to do so as to accomplish the activities. The language used is plain for ease of understanding and of following.

Remember is the part that anticipates possible concern a facilitator could experience in a specific activity. This part gives encouragement, suggestion on what to do so the session activity is maximized.

The drama activities were created with the aim of addressing the identified socialization deficits of the learners with ASD. Each session aims to achieve similar goal and has activities that are 
intended to enhance the learners' skills. The activities follow a certain order which see to it that the learners will not be overwhelmed in each session and will come to each session expectant of having more experiential learning. The hierarchical process starts with easy activities that level up as the learners proceed to the next blocks.

The first session focuses on the learners' understanding of their own selves individually. The guided sensory experiences will let the learners focus on their senses. This helps explore and address persons with ASD's sensitivities to different sounds, smells, tastes and textures in activities that were fun and exciting. The movement activities will make them move and experiment on different action. These are intended to give the learners the enjoyment of being free as they bring to life different animals and objects through their own movements. The activities are designed to enable them to practice socialization by pair and group. The activities will enable the learners to have less focus on themselves as they put their attention and energy on the tasks at hand.

The module is designed in such a way that all throughout the sessions, the learners will be guided by a facilitator in indulging in drama games, pantomime, movements, singing, role play and playmaking. The facilitator is the expert who directs the learners by scaffolding the skills they were learning. The learners were at their ZPD as regards understanding and developing socialization skills. They were unable to do the skills because of the limitations set by their condition. However, the facilitator will guide then in acquiring the new skills.

Pantomime is another helpful drama concept in the learners' acquisition of socialization skills. Limited by their condition, learners with autism are unable to show by acting out common actions that people do. Modeling by verbal instructions will enable them to demonstrate action of walking, jumping and running, drinking, or brushing their teeth. For typically developing learners, these everyday actions are part of their repertoire and were not needed to be rehearsed through miming. The actions come naturally. For learners with ASD, there is a need for rehearsal of actions to show their understanding because they normally lack the skill of imagination. Through the activities in drama, the learners were able to develop their imagination.

The creative drama module comes with an evaluation checklist that will help gauge the learners' demonstration and acquisition of socialization skills. The evaluation of a child's performance in creative drama activities developed by the researchers is composed of two parts. Part A Observation Notes is where an observer lists all the creative drama activities which the child will be participating in for twenty-one (21) sessions, at 30 minutes per session. Blank space is provided where the observer writes his or her observations concerning the performance of the child in each of the activities. Each child must have an Observation Notes form that should be accomplished during the workshop.

Part B Observation Checklist on Creative Drama for Socialization Skills Enhancement will be used in identifying if the child has manifested the skills under the observation items while undergoing the activities listed under the module outline. The observer is directed to put a check (/) under the 
"Yes" column to indicate that the behavior was observed within the duration of the specified activity; or under the "No" column to indicate that the behavior was not observed within the duration of the specified activity. For the column "Comments" the observer can write short descriptions in relation to what was ticked in the "Yes/No" column. Each child should have an Observation Checklist that should be accomplished after each creative drama session.

\section{Discussion}

The study identified the common socialization difficulties of learners with ASD. The social deficits exhibited by children with ASD impact their ability to successfully interact with same-age peers and adults which results in decreased opportunities to establish friendships and subsequent isolation from peers (Bauminger-Zviely, 2013). The exhibited difference in the learners with ASD's socialization has affected the way they responded to other learners who were typically developing, and on how these learners respond to them. Similarity involves their inability to interact even with their own peer group. Rather than join them in activities, the learners with autism would just stay isolated from the rest.

Modular instruction is one effective way of addressing a number of concerns among learners. According to Nardo (2017), modular instruction could be helpful to teachers in achieving the goals set for instruction. The holistic nature of a module will make it easy for the facilitator to see changes in the behavior of each learner as regards the social skills to be enhanced. The present study focused on the development and validation of a creative drama module. The concept of Drama as intervention tool started from people's realization that there are experiences and traumas in life that are too painful to address through the process of speaking about it. Drama could be considered as a powerful medium for learning among children with autism. Because of the nature of drama, its openness, its acceptance of any form of self - expression through creative movements, spontaneous lines or dialogues, it has a form of healing capacity that enables anyone of becoming. Varied researches have proven the effectiveness of using creative drama as an approach and strategy in teaching typically developing learners.

\section{Conclusion}

Children with autism manifest difficulties in socializing with others. The nature of their condition makes it difficult for this group of learners to develop and demonstrate interest in relating with others. However, the use of modular instruction involving drama activities could be used as tool to help learners with ASD to participate in reciprocal and interactive engagements with others.

\section{Corresponding Author}

Shirley N. Cerbo

Faculty of Education Sciences, Philippine Normal University, Manila, Philippines

Email: cerbo.sn@pnu.edu.ph 
INTERNATIONAL JOURNAL OF ACADEMIC RESEARCH IN BUSINESS AND SOCIAL SCIENCES

Vol. 9, No. 6, June, 2019, E-ISSN: 2222-6990 @ 2019 HRMARS

\section{References}

Adiguze, O. (2017). Creative drama in education (Egitimde yaratici drama) (10 $10^{\text {th }}$ ed.) Ankara: Pegem Academy. Retrieved from https://doi.org/10.14527/9786053644675

Agran, M., Hughes, C., Thoma, C. A., \& Scott, L. A. (2016). Employment social skills: What skills are really valued? Career Development and Transition for Exceptional Individuals, 39(2),111120

Bandura, A. (1976). The role of modeling processes in personality development. National Association for the Education of Young Children.

Bauminger-Zviely, N., Eden, S., Zancanaro, M., Weiss, P., \& Gal, E. (2013). Increasing social engagement in children with high-functioning autism spectrum disorder using collaborative technologies in the school environment. Autism: the international journal of research and practice (Vol. 17). https://doi.org/10.1177/1362361312472989

Biggs, J. (1999) Teaching for Quality Learning at University. Buckingham: SRHE/OU Press.

Caplan, B., Feldman, M., Eisenhower, A., \& Blacher, J. (2016). Student-Teacher Relationships for Young Children with Autism Spectrum Disorder: Risk and Protective Factors. Journal of Autism \& Developmental Disorders, 46(12), 3653-3666.

Carkin, G. (2007). Teaching English through drama. Retrieved from https:scholar.google.com.evotesoldrama2011.pbworks.com/f/teaching+through+drama.1 doc.

Conn, C. (2013). Play-based interventions for children and adolescents with autism spectrum disorders. Child \& Adolescent Mental Health, 18(2), 125-126. doi:10.1111/camh.12031_6

Donnelly, R., Fitzmaurice, M. (2005) Designing modules for learning. In G. O'Neill, S. Moore \& B. McMullin (eds.) Emerging issues in the practice of University Learning and Teaching, Dublin, All Ireland Society for Higher Education (AISHE).

Frith, U. (1991). Autism and Asperger Syndrome. Cambridge University Press.

Gates, J. A., Kang, E., \& Lerner, M. D. (2017). Efficacy of group social skills interventions for youth with autism spectrum disorder: A systematic review and meta-analysis. Published in final edited form as: Clinical Psychology Rev.; 2017 March; 52: 164-181. doi: 10.1016/j.cpr.2017.01.006.

Guido, R. (2014). Evaluation of a modular teaching approach in materials science and engineering. American Journal of Educational Research, 2(11), pp.1126-1130.

Gustavsen, A. M. (2017). Logitudinal relationship between social skills and academic achievement in a gender perspective. Cogent Education, 4(1), 1411035. Retrieved from https://doi.org/10.1080/2331186X.2017.1411035.

Karal, M. \& Wolfe, P. (2018). Social story effectiveness on social interaction for students with autism: Review of the literature. Education and Training in Autism and Developmental Disabilities, 53(1), 44-58.

Kemp, K. (2015). Teaching social skills to students with autism spectrum disorders and students with intellectual disabilities 
Kempe, A., \& Tissot, C. (2012). The use of drama to teach social skills in a special school setting for students with autism. Support for Learning, 27(3), 97-102. doi:10.1111/j.1467-9604.2012. 01526.x

Macnamara, R. (2015). A Group based intervention for children with special educational needs: Promoting social skills and communication through shared cooking activities in a mainstream primary school. Reach, 283-20.

Mc Caslin, N. (2006). Creative drama in the classroom and beyond. Boston: Pearson/Allyn and Bacon.

Nardo, M. T. B. (2017). Modular instruction enhances learner autonomy. American Journal of Educational Research, 5(10), 1024-1034.

Orkibi, H. (2013). The applicability of a seminal professional development theory to creative arts therapies students. Clinical Psychology and Psychotherapy.

Padmapriya, P. V. (2015). Effectiveness of Self Learning Modules on Achievement in Biology Among Secondary School Students. [online] ljepr.org. Retrieved from http://ijepr.org/doc/V4_Is2_June15/ij12.pdf

Schoenfield, N., Rutherford, R., Gable, R., \& Rock, M. (2008). ENGAGE: A blueprint for incorporating social skills training into daily academic instruction. Preventing School Failure: Alternative Education for Children and Youth, 52(3), 17-28.

Srinivasan, S., Eigsti, I., Gifford, T., \& Bhat. (2016). The effects of embodied rhythm and robotic interventions on the spontaneous and responsive verbal communication skills of children with Autism Spectrum Disorder (ASD): A further outcome of a pilot randomized controlled trial. Research in Autism Spectrum Disorders, 27, 73-87.doi: 10.1016/j.rasd.2016.04.001

Unchalee, S., Thidakorn, M. \& Kamonrat, S. (2013). Social skills deficits of students with autism in inclusive schools. Social and Behavioral Sciences. Vol. 116, 509-512.

Van Volkenburg, J. B. (2015). Reaching children with autism spectrum disorders using creative dramatics: The building blocks model. Dimensions of Early Childhood. Volume 43 No. 2.

Vygotsky, L. (1978). Mind in Society. Cambridge, MA: Harvard University Press.

Wentzel, K. R. (2015). Socialization in school settings. In J. E. Grusec \& P. D. Hastings (Eds), Handbook of socialization Theory and research (2 ${ }^{\text {nd }}$ ed., pp. 251-275). New York, NY: Guilford Publications.

Wheater, C. (2013). Theater therapy for children with autism. Fisher Digital Corporation. St. John Fisher College. 